\title{
IX. On the solvent action of drainage-water on soils
}

John Wilson Esq.

To cite this article: John Wilson Esq. (1847) IX. On the solvent action of drainage-water on soils, Philosophical Magazine Series 3, 30:198, 30-33, DOI: 10.1080/14786444708562619

To link to this article: http://dx.doi.org/10.1080/14786444708562619

曲 Published online: 30 Apr 2009.

Submit your article to this journal ๘

Џ Article views: 2

Q View related articles $\sqsubset$ 
In effect we solve (A.), (B.), (C.) and (D.), by means of $\Xi^{\prime}, \Xi^{\prime \prime}, \Xi^{\prime \prime \prime}$, $\Xi^{\mathrm{iv}}$; the remaining $\Xi$ 's (excepting $\left.\Xi^{(0)}\right)$ are determined in effecting the reduction of ${ }_{3} \mathrm{Y}_{n}^{\prime}$ to the form of (C.); and $\Xi^{(0)}$ will be obtained from $y^{\prime}=0$, after substituting in it the values of the other E's.

The above investigations give the formula

$$
\left.n(1,1,1,1) \text { (or, } n\left(1^{4}\right)\right)=9 ; \quad . \quad . \quad . \quad\left(317^{\prime \prime} .\right)
$$

and shows that the general equations of the NinTH and higher degrees may be transformed into others of the same degrees, from rohich the second, third, fourth and fifth terms disappear: the corresponding formula for $m$ (see the first part of this dis. cussion*) is

2 Church Yard Court, Temple,

$$
m(1,1,1,1)=11 \text { (or 10). . . }
$$

November 28,1846 .

Postscript, Dec. 14, 1846.-On looking over the proof-slip, I observe that, in this paper, I have not had occasion to use the foregoing notation for the roots of equations. But the above may be considered to suggest the following permanent notation; viz. that $x_{r}$ should represent a root, and $x^{(r)}$ the coefficient of the $(r+1)$ th term of an equation in $\mathrm{X} ;{ }_{r} \mathrm{X}$ a quantity composed of sym metric functions of, and homogeneous and of the $r$ th degree with respect to, $x_{1}, x_{2}, . x_{n}$; that $\xi$ should denote the disposable quantities which enter (explicitly) into the equation for $y$ and $\Xi$, the disposable quantities implicitly contained in that equation. When $r$ is given as a number, we may, however, as above, express the coefficients by accents if $r$ be small, or by Roman numerals if it be large. For facility of reference I have termed 'last' volume what was in fact the current one at the time of writing this paper.

IX. On the Solvent Action of Drainage-Water on Soils. By JoHN WiLson, Esq.†

I $\mathrm{N}$ the autumn of 1844, being a resident in East Lothian, 1 where the system of thorough draining is very extensively carried out, it occurred to me that the drainage-water during its percolation of the soil must necessarily dissolve out and carry away a great portion of the soluble constituents of it, which, by the practice as at present followed, are carried off the land and entirely lost to the farmer. I therefore took advantage of the first fall of rain sufficient to set the drains

* Phil. Mag. S. 3. vol. xxix. pp. 181-183. 1846.

+ Communicated by the Chemical Society; having been read May 4, 
running after the dry weather of the autumn, and collected some of the drainage-water, which I subjected to a partial analysis, the particulars of which were described in a paper read by Dr. W. Gregory at a meeting of the Royal Society, Edinburgh, in the early part of last year. The results I then obtained, though very incomplete, were quite sufficient to show me that they had a very important bearing on agriculture, and to induce me to go on with their further investigation.

About the usual quantity of rain had fallen during the time between November, when I collected the first sample, and April 29th, when I obtained the second, and during the whole of that period the land had laid ploughed as a winter fallow.

Immediately after the second sample was taken the field was prepared for seed and sown with guano and barley. In a few days after (May 16th) I was enabled to collect a third sample (of course from the same drains), and having submitted them to analysis, the following are the results:-

Second Sample.-18 lbs. of drainage-water on evaporation gave 15.2 grs. of solid residue, or about $\cdot 844 \mathrm{gr}$. to the pound.

Organic matter and water in combination $\mathbf{3 \cdot 4}$

Silica . . . . . . . . . . . 0.9

Silicate of alumina . . . . . . . . 0.4

Chloride of magnesium . . . . . $1 \cdot 12$

Chloride of sodium . . . . . . . 1.8

Chloride of calcium . . . . . . . $3 \cdot 0$

Sulphate of alumina . . . . . 0.85

Peroxide of iron . . . . . . . . $2 \cdot 1$

Phosphate of lime . . . . . . . 0.3

\section{$13 \cdot 87$}

Third Sample.-18 lbs. of drainage-water on evaporation gave $27.5 \mathrm{grs}$. of solid residue, or about $1.525 \mathrm{gr}$. to the pound.

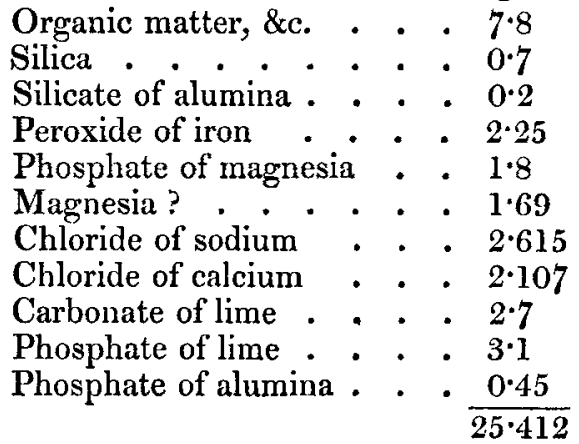

I should here observe that the first sample, collected in 
November, after the drains had been dry for many weeks previous, contained $2 \cdot 25$ grs. of solid residue to the pound; whereas that collected in the following April (No. 2), after the land had been continually drenched by the winter's rains, only gave $\cdot 844 \mathrm{gr}$. to the pound.

On adding a quantity of easily soluble manure (guano) to the soil, the first waters (No. 3) that passed through not only brought with them an increased quantity $(1.525 \mathrm{gr}$. to the pound), but they contained many of the very ingredients that constituted the value of the manure itself.

At the time the paper referred to was read at the Royal Society, Edinburgh, it was suggested that possibly the turbid portion first discharged from the drains after heavy rains might contain matter also very valuable to the soil; but on comparing the subjoined analysis with that of the drained soil, it appears to be composed of the same ingredients, with a decrease in the proportion of silica and an increase in the lime, both of which may be readily accounted for.

Analysis of Soil deposited from Turbid Drain-Water.

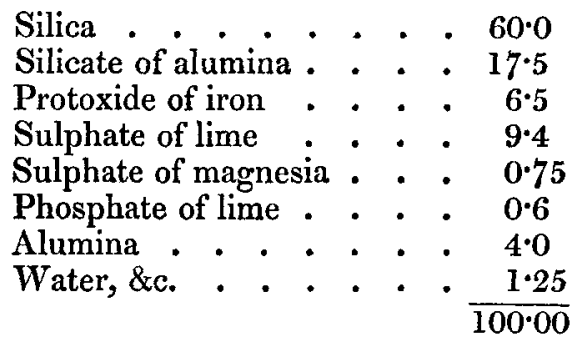

I do not for a moment wish to question the value of the principle of thorough draining; that is now I believe universally admitted; but if its results are deemed so beneficial to the farmer under the present practice, how much more so would they not become, if some remedy were devised either to prevent as much as possible this great abstraction, or else to render the enriched drainage-water again available to the soil!

This subject has not, I find, escaped the observant mind of Liebig, and in fact forms the basis of the 'Patent Manure,' according to his specification in October last. He has argued theoretically to the same end, and has proffered a remedy in the shape of a manure, by his patent process rendered much less soluble than before, which of course would not be acted upon so readily by the percolating rain-water, and would 
consequently remain longer in the soil for the purposes of vegetation.

Mr. Smith of Deanston, a man to whom practical agriculture is deeply indebted, has suggested the application of all manures whatsoever in a largely diluted liquid state, and which I am informed has been most successfully applied on the western coast of Scotland.

Now both of these plans will most assuredly tend to lessen the loss at present sustained; the one by diminishing the solubility of the manures employed, and the other by rendering the drainage-water again available.

But should the farmer object to take advantage of either plan, it would appear expedient to avoid using as much as possible the very soluble manures, and instead of giving his land the usual good dose of manure that is expected to suffice for two or three seasons, to divide the quantity, and to apply it in as small a proportion and as frequently as the nature of his crops will permit him to do. In such case his crops will get more and his ditches less than by the present practice.

$\mathrm{X}$. Report of Proceedings in the Cambridge Observatory rela. tive to the New Planet. By Professor Chaldis*.

St. Catharine's Hall Lodge, Dec. 12, 1846.

THE Syndicate appointed to visit the Observatory, concei1 ving the subject at the present time to possess peculiar interest, beg leave to submit to the senate the following statement of Prof. Challis, describing the course of observations, founded on the theoretical calculations of Mr. Adams of St. John's College, and made at the Observatory, with a view to the discovery of the new planet.

$\begin{array}{cl}\text { H. Philpott, Vice-Chancellor. } & \text { G. Peacock. } \\ \text { John Graham. } & \text { James Cartmell. } \\ \text { B. Chapman. } & \text { Chas. W.Goodwin. } \\ \text { W. Whewell. } & \text { W. C. Mathison. } \\ \text { Joshua King. } & \text { G. G. Stokes. }\end{array}$

At a meeting of the Observatory Syndicate, held at the Observatory on December 4, for the despatch of ordinary business, a strong desire having been expressed by the ViceChancellor and the members of the Syndicate generally, to receive from me a special report of observatory proceedings relating to the newly-discovered planet, drawn up in such a manner, and in such detail, as would enable them to lay complete information on the subject before the members of the

* Communicated by Professor Challis.

Phil. Mag. S.3. Vol. 30. No. 198. Jan. 1847. 